\title{
KSHV interaction with Langerhans and dermal dendritic cells through C-type lectins
}

\author{
Giovanna Rappocciolo*, Mariel Jais, Paolo Piazza, Frank Jenkins, Charles Rinaldo \\ From $12^{\text {th }}$ International Conference on Malignancies in AIDS and Other Acquired Immunodeficiencies \\ (ICMAOI) \\ Bethesda, MD, USA. 26-27 April, 2010
}

The skin contains two types of dendritic cells (DC), Langerhans cells (LC), which reside in the epidermis in close contact with keratinocytes, and dermal dendritic cells (DDC), resident in the dermis. LC and DDC process cutaneous antigens and migrate out of the skin into the draining lymph nodes to present antigens to $\mathrm{T}$ and $B$ cells. Recent reports showed that LC and DDC play an important role in certain virus infections, such as HIV-1 and HSV. Because of the strategic position of LC and DDC at mucosal sites of infection and the ability of these cells to capture pathogens, we hypothesized that these cells could be infected with KSHV and have an important role in the development of Kaposi's sarcoma. We have previously shown that KSHV enters monocytederived dendritic cells (MoDC) through DC-SIGN, resulting in a nonproductive infection. We have now generated LC and DDC from pluripotent cord blood CD34+ precursors by culture with GM-CSF, TNF, and TGF-B to obtain LC, and GM-CSF, TNF, and IL4 to generate DDC. These expressed the typical phenotype of $\mathrm{LC}$, i.e., $\mathrm{CD} 207^{\text {pos }}, \mathrm{CD} 14^{\text {pos }}, \mathrm{CD} 11 \mathrm{~b}{ }^{\text {neg }}, \mathrm{CD} 1 \mathrm{a}^{\text {pos }}$, HLA$\mathrm{DR}^{\text {pos }}, \mathrm{DC}$ SIGN ${ }^{\text {neg }}$, and dermal DC, i.e., $\mathrm{DC}^{-S I G N}{ }^{\text {pos }}$, $\mathrm{CD} 14^{\text {neg }}, \mathrm{CD}_{11 b^{\text {pos }}}, \mathrm{CD} 1 \mathrm{a}^{\text {pos }}, \mathrm{HLA}^{-\mathrm{DR}^{\text {pos }}}$, langerin $^{\text {neg }}$. We found that both LC and DDC supported productive infection with KSHV. Strikingly, while the level of viral DNA replication increased only 4-fold in infected DDC by $24 \mathrm{~h}$, we observed a $>1 \log _{10}$ increase in levels of viral DNA in LC. Anti-DC-SIGN mAB inhibited viral infection of DDC as detected by expression of viral proteins and viral DNA, while blocking of langerin on LC did not interfere with viral entry and replication. Infection with KSHV did not alter cell surface expression of langerin on LC, but downregulated expression of DC-SIGN

*Correspondence: giovanna@pitt.edu

Department of Infectious Diseases and Microbiology, University of Pittsburgh, Pittsburg, PA, USA on DDC, as we previously reported for MoDC. Cytokine production in infected LC and DDC was also altered compared to uninfected cells, with an increase in the levels of IL-8, IL-6, and IL-10 in the infected cells. These results indicate that KSHV can target both LC and DDC for productive infection and alter their function, supporting a role for these dermal DC in KSHV infection and pathogen.

\section{Acknowledgements}

This article has been published as part of Infectious Agents and Cancer Volume 5 Supplement 1, 2010: Proceedings of the $12^{\text {th }}$ International Conference on Malignancies in AIDS and Other Acquired

Immunodeficiencies (ICMAOI). The full contents of the supplement are available online at http://www.biomedcentral.com/1750-9378/5?issue=S1 .

Published: 11 October 2010

doi:10.1186/1750-9378-5-S1-A48

Cite this article as: Rappocciolo et al:: KSHV interaction with Langerhans and dermal dendritic cells through C-type lectins. Infectious Agents and Cancer 2010 5(Suppl 1):A48.

Submit your next manuscript to BioMed Central and take full advantage of:

- Convenient online submission

- Thorough peer review

- No space constraints or color figure charges

- Immediate publication on acceptance

- Inclusion in PubMed, CAS, Scopus and Google Scholar

- Research which is freely available for redistribution

Submit your manuscript at www.biomedcentral.com/submit
C Biomed Central 